\title{
VERZUIMD ST. EUSTATIUS ${ }^{1}$ ) \\ DOOR
}

PROF. DR. L. KNAPPERT

De beoefening van de geschiedenis onzer handelskerken bracht den schrijver der volgende bladzijden herhaaldelijk (helaas alleen maar in den geest!) naar de $\mathrm{Ne}-$ derlandsche Bovenwindsche eilanden, en uit die kennismaking ontstond de begeerte hare historie te boek te stellen. Hamelberg is niet verder gekomen dan 1703. In 1781 valt de verwoesting van St. Eustatius door Rodney. Wat daarop volgt is menigmaal verhaald, maar juist die tachtig jaren der 18de eeuw zijn voor velen onbekende grond en toch kan hun geschiedenis uit de wel deerlijk gehavende (voor een deel verloren) maar toch nog rijke archieven worden opgebouwd. Dat ik mij daartoe heb gezet, geschiedde ook (waartoe het verzwegen?) uit een gevoel van ridderlijkheid tegenover dit wel zeer verwaarloosde stukje van het Nederlandsche Rijk. De kennis van het verleden zal ook hier de belangstelling in het heden ten goede komen. Om dat tegenwoordige is het mij op het oogenblik te doen; van de geschiedenis der eilanden haal ik alleen iets op van wat helpt, om wat nu geschiedt beter te doen begrijpen. Voor de kennis van dit laatste stonden mij tal van tijdschriftartikelen en brochures ten dienste, voorts de Tweede Kamer-verslagen, ook brieven van eilanders, die de taak van een ontbrekende pers op zich namen. Dankbaar vermeld ik de voordracht van Mej. Slothouwer, Zaterdag 27 April voor de groep West-Indië van het Indisch genootschap gehouden, waarmede ik nog juist mijn voordeel kon doen. Hen die

$\left.{ }^{1}\right)$ Voordracht, gehouden in de maandvergadering van de Maatschappij der Nederlandsche Letterkunde te Leiden den 3den Mei 1929. 
de fraaie door haar vertoonde lichtbeelden hebben gezien, zal de schoonheid getroffen hebben eener natuur, waarvan, trots meedoogenlooze ontbossching, zich nog zooveel heeft gehandhaafd.

In 1635 beginnen Jan Snouck en andere Zeeuwen St. Eustatius te koloniseeren, dat dus niet, als Curaçao, van den aanvang bezitting der W. I. Compagnie, veeleer een leen onder min of meer zelfstandige patroons met ambachtsheerlijke bevoegdheden was. Niettegenstaande herhaalde overvallen van Engelsche en Fransche boekaniers kon de tabak- en katoen-aanplant en vervolgens die van suikerriet er zich ontwikkelen en was er geen onaanzienlijk handelsverkeer met de omliggende eilanden. Sint Maarten was reeds in 1648 bij verdrag half Nederlandsch, half Fransch geworden; toch meende nog in 1703 de commandeur van St. Eustatius, Isaäc Lamont, toen hij het eiland bezette, dat hij het „veroverd” had. Intusschen gold het nadien, met korte onderbrekingen, in zijne Zuidelijke helft voor Nederlandsch gebied. Begin 1682 verkochten de erfgenamen der oude patroonsfamilies Van Ree en Van Perre St. Eustatius en Saba aan de W. I. C. Sinds gold St. Eustatius voor het hoofdeiland, waar de commandeur woonde, sinds 1700 ettelijke jaren met een tweeden naast zich, terwijl op St. Maarten en Saba vice-commandeurs zetelden. Op elk eiland was een secretaris, op St. Eustatius ook een fiskaal, die van de Comp. hun mandaat ontvingen. Doch de eilanders zelven hadden invloed op de samenstelling van den Raad, voor de leden waarvan, vijf op St. Eustatius, vier op de beide andere eilanden, zij den commandeur dubbeltallen aanboden. Tot hen behoorde ook de kapitein van de burgerij. Onder alles door treft ons dat er geen organisch verband met Curaçao bestond, en dat men op die onafhankelijkheid prijs stelde. Wanneer in Januari 1717, de oude commandeur Jan Simonsz. Doncker ziek te bed ligt, beveelt hij aan Heeren X een paar burgers als zijn opvolger aan, maar nooit, hoopt hij, zullen zij een Curaçaonaar kiezen, omdat die de eilanders haten. In ons bewaard ge- 
bleven curieuse brieven van eene Curaçaosche familie $\mathrm{a}^{\circ}$ 1709 heeft zij het over dat ruwe land met die wilde Statianen, maar toont zich zelve vooral niet beschaafder. Dat gevoel van zelfstandigheid tegenover het parmantige Curaçao vindt men telkens. In het heksenproces op St. Maarten ten jare 1711 en volgende, waarover ik in den jaargang 1928 van dit tijdschrift handelde, gaven Heeren $\mathrm{X}$ verlof den genoemden Doncker voor den Raad van Curaçao te dagvaarden. Hij schreef toen naar patria, hoe het hem ergerde, dat men aldus tornde aan een oud voorrecht, dat die van St. Eustatius nl. altijd hun ,vrije gerigte hebben gehad en noyt onder directie van Curaçao hebben gestaan”. „Waarom”, vraagt hij, ,mij niet voor UE. Agtb. eygen vierschaar gedagvaard?" Ja zelfs schijnen er mij nog sporen te bestaan van de meening, dat de overdracht aan de Compagnie eigenlijk een vrijheidsverlies was geweest. Tijdens moeielijkheden, op St. Maarten, gerezen tusschen den opgedrongen commandeur Louis Guillaume Durepaire en de burgerij, 1719, zou volgens hem een hunner gezegd hebben, dat de kooplieden van Middelburg en niet Bewindhebberen hun meesters waren ${ }^{\mathbf{1}}$ ). Van dit gevoelen heb ik echter geen verdere bewijzen gevonden; hoofdzaak is, dat onze eilanden zich van ouds als zelfstandig hebben beschouwd, onder rechtstreeksch gezag van de Heeren in patria. Het is waar, dat dezen, „onze voorsienige Meesters”, die beschouwing niet onveranderlijk deelden: zij hebben wel eens centralisatiegedachten trachten te verwezenlijken en hunne bevelen kwamen vaak via den Directeur van Curaçao. Eerst in 1845 werden „de koloniën” St. Eustatius en Saba alsmede St. Maarten vereenigd met de kolonie Curaçao.

De taal is Engelsch geworden. Men kan het proces van stap tot stap uit de archiefstukken volgen. Het begint met onze taal naar Zeeuwschen tongval, dat ook op St. Thomas, St. Jan en St. Kruis in zwang raakt en daar, volgens de onderzoekingen van Hesseling en De Josselin de Jong, het Negerhollandsch deed ontstaan. Op onze ei-

$\left.{ }^{1}\right)$ Durepaire aan Doncker jun. d.d. St. Maarten 5 Avril 1719, Brieven van St Eustatius portef. no. 2 fol. 502r R.-A. 
landen dan waren prediking, onderwijs en rechtspraak, de briefwisseling tusschen de ambtenaren en het moederland, de cognossementen, facturen, rekeningen en scheepslijsten, ook de onderlinge omgang in het Nederlandsch, onderhouden en gevoed door voortdurende immigratie van vaderlandsch personeel. Maar het Engelsch begint op te komen. Men bespeurt dat b.v. in de doop- en trouwboeken, waar Engelsche voor- en achternamen al talrijker worden en ,peter' en ,meter', godfather' en ,godmother' gaan heeten. Op het eind der 18de eeuw heeft het Engelsch, vooral door de sterke Amerikaansche betrekkingen, de overhand. Sommigen gaan daar nog wel krachtig tegen in; Juli 1780 zegt ds. Reneman van St. Maarten, dat de Nederlandsche taal, vooral onder de kinderen,daar bijna vergeten is, doch dat de komst van den nieuwen schoolmeester Martinus Hartman daarin verbetering zal brengen; maar de ondergang blijkt niet te stuiten. Op de Deensche Antillen, waar de hervormde gemeenten Nederlandsche predikanten beriepen, ging onze taal eerst op het einde der eeuw te loor, ook door de vele Engelsch sprekendeStatianen die in 1781 daarheen gevlucht waren. Op onze eilanden bleef het Nederlandsch natuurlijk wel de officieele taal, maar na 1816, wanneer zij weder onder vaderlandsche vlag gekomen zijn, begint de schandelijkste verwaarloozing. Wat baatte het, dat de twee talen op de scholen behoorden geleerd te worden, waar het gouvernement zelf aan de verdrukking mededeed? Wel is waar kwam daarin in deze eeuw verbetering dank zij gouverneur De Jong van Beek en Donk en ik denk o.a. ook aan den prachtigen arbeid van Mej. Slothouwer op St. Maarten, deswege zelfs door het Plein geridderd, maar „wat baat die groene en gouden loover?" De staatsie van het Nederlandsch is over. De prediking der Wesleyanen en Anglicanen is natuurlijk Engelsch, tegenwoordig ook die der R. K. geestelijken, de Ned. Herv. Kerk, 1755 ingewijd, staat, van dak, preekstoel en banken beroofd, op den rand van het klif als een droevig beeld van de verwaarloozing ook van den Nederlandschen eeredienst. De rechtspraak geschiedt in het Engelsch; toen men in 1898 
de troonsbestijging der koningin vierde, had men de volksliederen in het Engelsch vertaald.

Want - de geschiedenis der Nederlanders in NoordAmerika, onlangs door dr. J. van Hinte zoo uitnemend beschreven, herinnert er ons ook aan - verlies van taal is nog geen verlies van stambewustzijn en nationaliteitsgevoel. De Amerikaan Frederic Fenger maakte in 1916 in eene kleine zeilboot een tocht langs dezen ganschen eilandengordel en komt en blijft lang op St. Eustatius en Saba, waar, vertelt hij, Nederlandsche zeden en gewoonten, maar vooral gevoelens zich handhaven ${ }^{1}$ ). Dat bewijst ook de algemeene viering der koninklijke verjaardagen. Neen, onze eilanden doen te dezen œzichte voor Suriname niet onder, en de tegenwoordige Los-vanCuraçao beweging (wij gaan het zien) is stellig niet antiNederlandsch.

Het is ten slotte de moeite waard, in deze weinige historische aanteekeningen vast te stellen, dat onze eilanden landbouweilanden heeten moeten, in tegenstelling met Curaçao wederom, dat handelscentrum was. De kaart van Reinier Ottens 1775 geeft de 76 plantages, waarmede St. Eustatius toen was overdekt, waarop katoen, suiker, kokosnoten, oranjeappelen welig tierden. In 1731 beroemt een planter er zich op dat hij-alleen voor 6 à 700 okshoofden suiker jaarlijks belasting betaalde. Uit de scheepslijsten neem ik er een van 5 Juli 1734 tot 19 November 1735, zij geeft 23 schepen met suiker naar Amsterdam, waarvan \pm de helft Engelsche namen dragen. Van St. Maarten bedroeg de uitvoer van 16 Februari 1734 tot dien datum in 1735, behalve 12000 pond van het dure fustikhout en 16318 van het niet minder voortreffelijke pokhout (lignum vitae), $24748 \frac{1}{2}$ pond katoen en 180037 pond suiker. Het is waar, dat de groote rijkdommen van St. Eustatius in de jaren vóór 1781, waarom het de Gouden Rots heette, uit den handel voortvloeiden, met name toen het eiland het doorvoercentrum was voor de Amerikaansche opstandelingen, maar dit mag nimmer doen

1) Fr. A. Fenger, Alone in the Caribbean, N. York 1917 pag. 289-326. 
voorbijzien, dat St. Eustatius en St. Martijn van nature landbouw en veeteelteilanden waren - en zijn.

„Verzuimd”. Zoo is het op het oogenblik met onze Bovenwindsche eilanden inderdaad. Daar is vooreerst het ontaarde bestuursstelsel. Een slecht stelsel kan met voortreffelijke ambtenaren nog wel tot iets goeds leiden, maar ontbreken die, dan werkt het dubbel noodlottig. Ik zal meer van het stelsel dan van de personen zeggen, van de laatsten slechts dit, dat in geen der stukken en brieven, die mij onder oogen kwamen, ook maar iets tot hun lof staat. Ook de volgende bladzijden zullen toonen, dat het voorzichtigst oordeel toch de algemeene ontevredenheid gerechtvaardigd moet achten. De w.n.d. gezaghebber der drie eilanden, de heer W. F. M. Lampe, is niet de man van rijpe en bezonnen ervaring, die wat van de wereld gezien heeft, met de gaven en krachten voor zoo belangrijk een post gewenscht. De pl.v.v. gezaghebber van St. Eustatius de heer E. S. J. Kruythoff, een kleurling, is meteen hoofd der openbare school en ambtenaar van het Openbaar Ministerie. Hij is geboren en getogen op St. Maarten. Zijne sympathieën gaan niet uit naar zijne eigene kleurgenooten, terwijl die toch de overgroote meerderheid der bevolking uitmaken. De ontvanger is een vrouw, mejuffrouw Jolanda Lampe, oomzegster van den gezaghebber en volgens de berichten voor haar werk ongeschikt. Ik kan op dit punt slechts weergeven, maar bij, naar mijn weten, gezaghebbende getuigen lees ik van de „wan-administratie” op St. Eustatius en dat „de tegenwoordige stand van zaken een schande is voor het Nederlandsch gouvernement". Over den waarn. gezaghebber op Saba, den heer X. H. C. M. Krugers, is mij geen getuigenis onder oogen gekomen.

Doch thans het stelsel. Tengevolge van de ontzaglijke industrialisatie van de omgeving van Willemstad kan het gebiedsdeel Curaçao uit zijn midden geen ambtenarencorps meer op behoorlijk peil houden. Daaronder lijdt natuurlijk het bestuurswerk, dat aan de op Curaçao samengetrokken administratie ondergeschikt is; van dat 
werk zooals het zijn moet d. w. z. het leven met, het kennen van het volk komt niets te recht.

In 1919 kwam de heer G. T. Tymstra op St. Martijn als de eerste der gemeenschappelijke gezaghebbers, volgens de bepaling dat de onderscheiden eilanden der kolonie, behalve Curaçao, ook groepsgewijze onder een gezaghebber kunnen staan. Hij was een man van goeden wil, van idealen, maar geen bureaucraat en legde het al spoedig af tegen den centraliseerenden geest in Willemstad. Welnu, bij zijn komst schreef de „Saint Martin Day by Day", dat grappig, lilliputtersch krantje, in zijn nummer van 31 Mei 1919: „Zullen wij nu een eigen bestuur krijgen, gescheiden van Curaçao? Zullen er nu wetten zijn die ons beschermen tegen de Curaçaosche ambtenaren? Zal Nederland onpartijdig onze belangen behartigen, zonder alles eerst aan het oordeel van Curaçao te onderwerpen?"'Ziedaar drie vragen, die ons midden in de zaak brengen en die helaas alle drie ontkennend moeten beantwoord worden. Reeds aanstonds, dat St. Maarten de hoofdplaats werd, was verkeerd gezien. Van ouds was St. Eustatius dat geweest, en men had historische rechten behooren te ontzien, begrijpelijke gevoeligheden moeten sparen. Doch vooral was het een misgreep om onze eilanden van Willemstad uit te doen besturen. Met miskenning van elk recht van zelfbeschikking maakte de hooge politiek van het moederland één gebied van die twee eilandengroepen, die in geschiedenis, in klimaat, bodem, fauna en flora zóó ver uitéénloopen, waarbij het overwicht geheel aan Curaçaosche zijde was. Men wist in het „landbouw-nihilistisch” Willemstad niet veel van de levensvoorwaarden onzer eilanden en verwaarloosde ze schromelijk. En zij konden geen stem daartegen laten hooren. De koloniale Raad op Curaçao, die tegen letter en geest van het regeeringsreglement over hun wel en wee beschikt, is geen volksvertegenwoordiging, waarin afgevaardigden van alle eilanden zitting hebben, maar een oligarchisch college, zoo ongeveer als vroeger in ons land een regenten-kabale. En deze Raad heeft het recht gelden toe te staan of te weigeren voor de Bovenwindsche Eilan- 
den en kan op die manier in de vitale aangelegenheden ervan ingrijpen, zonder dat zij zich verweren kunnen tegen welk onrecht ook, want het Plein is practisch uitgeschakeld. Is het wonder, dat men van dien kolonialen Raad los wil en, gelijk de Engelsche Antillen voor hunne zelfstandigheid, slechts in de Hooge Regeering de waarborg ziet voor een rechtvaardig en oordeelkundig bestuur? Is het wonder, dat men in bitterheid uitroept: ,wij zijn geen stroopersgebied van Willemstad. Wij zijn Nederlandsche gemeente en mogen zoo goed op zorg aanspraak maken als Vlieland of Urk!"' Naar mijne meening heeft vooral St. Eustatius onder dit averechtsch stelsel te lijden. De gezaghebber woont op St. Maarten en besteedt daar wel enkele gelden, maar men besnoeit op de noodigste uitgaven voor Statia, het historisch centrum der groep en het productiefste. Dit verlangen om los van Curaçao te komen is in het geheel geen rebellie, gelijk ik al zeide, maar eene uiting van verlangen naar zelfbeschikking onder rechtstreeksch toezicht van het Moederland ${ }^{\mathbf{1}}$ ).

Het is aangenaam te kunnen vaststellen, dat ook enkele leden der Tweede Kamer in dezen geest hebben gesproken. In de zitting van 13 December 1928 zeide de heer Yzerman: „Wanneer de medewerking der StatenGeneraal niet meer vereischt wordt tot vaststelling der begrooting van Curaçao, is dit hoofdstuk (XIde hoofdst. 13de afd.) de aangewezen gelegenheid ter bespreking van vraagstukken, die het regeerbeleid ten aanzien van Curaçao betreffen. De herziening van het Regeeringsreglement is noodig geworden sinds de jongste grondwetswijziging, die immers de inwendige aangelegenheden van een gewest aan de aldaar bestaande organen overlaat. De Kamer heeft dus geen zeggenschap over aangelegenheden, waarvan de regeling aan die organen in Curaçao dient te worden overgelaten. Dus politieke mondigheid. Maar dan moeten er ook door de bevolking aangewezen vertegenwoordigers zijn. En die zijn er niet op Curaçao, want de koloniale Raad is” (ik haalde dit beeld al aan) ,als een

1) Zie Oost en West van 10 en 16 Mei 1928. Koloniaal Weekblad Sept. 1928. 
Oudhollandsch regentencollege. Daarom is de macht van den gouverneur zoo groot. Maar van zijn beleid" (bedoeld is de afgetreden gouverneur Mr. Brantjes) „zeide onlangs het koloniaal Weekblad: „,,Een politiek zonder gestadigheid, zonder waarborg voor den dag van morgen, zonder moreelen invloed, maar van een zeer ruim geweten,van alles los behalve van de petroleum"'". Aldus de heer Yzerman. De heer Van Vuuren sprak in het bijzonder van onze eilanden als door Curaçao verwaarloosd. De heer Joekes wilde een kolonialen Raad, die de zes eilanden zuiver vertegenwoordigde. En de heer Bijleveld wenschte zelfs voor de Bovenwindsche Eilanden eene eigen ordening met rechtstreeksche ondergeschiktheid aan Nederland ${ }^{1}$ ). Dit laatste ware stellig verreweg het beste; met wat Mr. Joekes wenschte, waren wij althans reeds een eind op den goeden weg.

De lezer heeft recht op enkele bewijzen voor die verwaarloozing van de belangen onzer eilanden. Daar is dan de landbouw. Zij die mogen meespreken over deze aangelegenheid hebben altijd betoogd, dat bij doelmatige overheidszorg gezonde landbouwtoestanden kunnen ontstaan. Maar dan moeten dat ook ernstige pogingen zijn. In eene vergadering van het Indisch Genootschap heeft de heer Menkman terecht gezegd, dat de pogingen, om de agrarische toestanden op de Bovenwindsche Eilanden te verbeteren, zóó spoedig zijn opgegeven, dat men uit het falen daarvan geene gevolgtrekking hoegenaamd maken mag ${ }^{1}$ ). Ook mag in landbouwgewesten de emigratie nimmer worden aangezien voor den grondslag van welvaartspolitiek. Over die emigratie zullen wij nog opzettelijk spreken, maar het is duidelijk, dat men aan landbouwstreken geen arbeidskrachten onttrekken, maar ze hun juist toevoeren moet. $\mathrm{Al}$ verder moet het gouvernement de genezing niet zoeken in geldelijke steunverleening zonder meer, want dat is wezenlijk een premie zetten op ledigheid, maar in het leeren van het modern landbouwbedrijf door voorlichting van geoefende landbouwers, door

1) Verslagen der Tweede Kamerzitting op 13 Dec. 1928 blz. 1057-1068.

2) Handelsblad van 13 October 1928, Ocht. III. 
invoer van landbouwwerktuigen en door de herplaatsing van den landbouwkundige op St. Eustatius. Van St. Maarten is er nog altijd uitvoer van melk, boter en eieren, ook naar Curaçao; daar zou de regeering aan de moderne vee- en hoenderteelt haar aandacht moeten wijden.

Wat de producten aangaat - katoenbouw, leeren ons de deskundigen, past voor St. Eustatius nog altijd het best. Ik ben op dit punt tot zelfstandig oordeel volstrekt onbevoegd en geef slechts hun meening weer. Het gouvernement nl. stelde een gesloten seizoen in, zoodat in dien tijd elk katoenplantje moest worden uitgetrokken, of het een goed tweede beschot beloofde of niet. Op eene vergadering van kleine planters bleek toen algemeene afkeuring van dien maatregel, zonder dat het verbod (met strenge strafbepalingen) werd opgeheven. De maatregel was gericht tegen een insectenplaag, maar in elk geval ging de animo voor katoen er door te niet. En het is mogelijk de katoenteelt te steunen. De Engelsche Antillen deden het met de Sea-Island-katoen, de fijnste der wereld, met schoone, zijde-achtige, sterke en lange vezel. Wanneer straks fabrikanten zakdoeken en kousen van die zijdekatoen op de markt brengen, vischt St. Eustatius weer achter 't net. Indertijd heeft de heer G. J. van Grol, toenmaals gezaghebber van het eiland, prachtig werk voor den wederinvoer van de katoen- en andere cultures gedaan. Groote en kleine landbouw bleken naast elkaar bestaanbaar en de kleine man kon zich (anders dan op St. Maarten) oeconomisch vrij maken, zoodat er zich een landarbeidersstand ontwikkelde, maar de Pink-Boll-worm, in 1922 op St. Eustatius gevondenen de wereld-malaise brachten toen zwaren tegenslag. De oude plantage-gronden leden, sinds de afschaffing der slavernij, onder gebrek aan arbeiders en op dit oogenblik worden ze of beplant met yams, maïs en zoete aardappelen, of voor weiland gebruikt, of verwaarloosd zoodat ze met ruw struikgewas begroeid zijn. Maar tusschen den Kuil en de noordelijke berggroep liggen nog altijd $5 \mathrm{~K} . \mathrm{M}^{2}$. prachtige cultuurgrond, niet alleen voor katoen, maar ook voor uien, cassave en tuingroenten geschikt. Ja, waarom zou men hier niet kunnen 
bereiken wat Montserrat, Dominica en Antigua hebben bereikt: bloeiende ananas- en limoentjes-cultuur of de Engelsche Virginische eilanden: muscovadosuiker, tabak en riet? ${ }^{1}$ ).

In de tweede plaats wijs ik er op, dat de begrooting van 1928 belastingvrijdom wilde. $\mathrm{Nu}$ is dat niet alleen een uiterst primitief beroep op het volksinstinct, maar vooral een getuigschrift van onvermogen en een soort van faillietverklaring. Men wil dat dan op St. Eustatius ook allerminst, men vraagt geen vrijdom van redelijke belasting, maar slechts eenige zachtheid bij de invordering van landrente in slechte tijden. Met name vestig ik de aandacht op de voorgestelde afschaffing van accijns op gedistilleerd. Deze zou natuurlijk de insulaire smokkelarij op St. Maarten, van het Fransche naar het Nederlandsche deel, doen ophouden. Maar zij zou meteen van onze eilanden smokkelnesten maken, van waar uit nationale en internationale drankhandel de landen in en om de Caraïbische zee van gedistilleerd zou voorzien. De Amerikaansche kustwacht heeft al eens een schoener van St. Maarten beschoten. „Is het oorbaar”, vraagt Oost en West van 16 Mei 1928, ,dat Willemstad ons de rum- en jeneverflesch en de Hamburger foesel voor den mond wil zetten onder sanctie van den Nederlandschen wetgever?"

Ik ga thans enkele grieven der eilanders tegen het $\mathrm{Cu}-$ raçaosch bestuursbeleid noemen, die wel is waar van onderscheiden aard zijn, maar toch alle op die verwaarloozing betrekking hebben, waartegen deze bladzijden opkomen. Daar is de reeds genoemde emigratie. St. Eustatius raakt ontvolkt en het bestuur (b.v. de vorige gezaghebber Beaujon) werkte dat nog in de hand. Men gaf nl. den menschen vrijen overtocht naar Curaçao, waar zij dan bij de Petroleum $f 2$ per dag verdienen. In twee jaren heeft men aldus een 300 mannen en vrouwen naar Curaçao gelokt, deze laatsten als dienstpersoneel, van wie de

1) G. J. van Grol, Economische arbeid op Sint-Eustatius van gouvernementswege, $1903-1918$, in W. I. Gids 1920; G. van der Plaats, Eenige beschouwingen over de toekomst van den landbouw op de Bov. Eilanden in W. I. Gids 1923. 
meesten begeeren terug te keeren. Doch thans geeft het gouvernement geen vrijen terugtocht. En, terwijl de Engelschen op hunne eilanden tegen ondoordachte landverhuizing waken, mag Curaçao ons eiland, dat zijn eigen kost verbouwen kan, van zijne beste krachten berooven.

Op St. Maarten verloopt om dezelfde reden de aloude zoutindustrie, omdat er geen arbeiders meer zijn om de booten te bemannen, die het zout over den zandrug naar de schepen brengen. Toch was dit zout op de Amerikaansche markt zeer gewild.

Dit gebrek aan menschen doet ook de visscherij verloopen en den kleinen land- en tuinbouw.

De watervoorziening in de „country” van St. Maarten laat alles te wenschen over. In Philipsburg is voldoende regenwater, t. w. twee groote bakken bij de Oranjeschool, maar voor de gekleurde bevolking op het land, die soms uren ver in blikken water moet halen, is een waterreservoir zeer noodig.

Aan de verbetering van den veestapel behoorde veel meer zorg besteed te worden. Het gouvernement had er een stier, maar heeft dien, ben ik goed ingelicht, aan een particulier verkocht.

Het personeel der Draadlooze op St. Maarten heeft men ingekrompen door den chef en den chefmonteur naar Curaçao terug te roepen.

De oude, afgekeurde en afgedankte schoolbanken van Curaçao en Aruba heeft men naar de Oranjeschool op St. Maarten gezonden,waar elke dokter en elke inspecteur van het onderwijs ze altijd weer afkeuren.

Op Saba diende Curaçao den zeeliedenstand (want verreweg de meeste mannen varen daar op zee) te helpen, vooreerst door de hoognoodige inrichting van een Draadlooze en dan door een betere landingsplaats. Ook moest daar een hôtel komen voor Amerikaansche toeristen, van wie er verleden jaar enkelen waren en die er het klimaat heerlijk vonden. Van de kantwerkindustrie op Saba toonde Mej. Slothouwer bij haar genoemde voordracht fraaie staaltjes, maar het schijnt dat ze te duur is voor onze markt. 
Een paar jaar geleden bouwde men te Bottom op Saba voor $f 14000$ eene school, maar dekte die, uit onkunde met de toestanden, niet met shingles, houten, vastgespijkerde dekspanen, maar met pannen. Reeds aanstonds kwamen er lekkages - Saba is geen droog en orkaanvrij Aruba! - en thans heeft de orkaan van September het dak meegenomen en den ganschen schoolinventaris vernield.

Over de lage bezoldiging der protestantsche geestelijken is vóór een paar jaar al geklaagd. Op St. Maarten en St. Eustatius staan Methodisten-leeraars, op Saba een Anglikaan, allen op $f 2400$, terwijl de geneeskundigen er $f 6000$ genieten.

Deze en dergelijke wenschen en grieven zijn telkens geuit, luide of zacht, zonder dat ze wezenlijk verder doordrongen dan Curaçao. Hier te lande, vanwaar toch de sterke drang tot verbetering en recht doen moest uitgaan, trokken ze nauwelijks de aandacht. Totdat de gebeurtenissen na den laatsten orkaan ook hier de gemoederen althans eenigszins hebben opgeschrikt. Hij woedde over onze eilanden 12 en 13 September 1928, d. w. z. hij liet St. Maarten nagenoeg ongedeerd, trof Saba, maar trof St. Eustatius viermaal erger. Daar vernietigde hij 40 en beschadigde een 130 huizen, doodde veel groot en klein vee, veroorzaakte belangrijke schade aan vischmateriaal en vaartuigen, alles te zamen tot een geraamd bedrag van $f 50,000$. Een poos daarna kon men lezen, dat twee opgezetenen van St. Eustatius, J. S. van Putten en J. G. Lespier zich met een adres tot den gouverneur van $\mathrm{Cu}$ raçao hadden gericht, waarin zij scherpe critiek oefenden op de houding van den plaatsvervangenden gezaghebber, den heer Kruythoff, na den stormramp en om verbetering van bestuur vroegen. Men vond dat stuk op het regeeringsbureau te Curaçao ongepast, vermits het in strijd was, durfde zijn, met het rapport van den heer Lampe, die immers had verklaard, dat wat gedaan moest worden ook gedaan was. Doch men stelde het adres toch in handen van de commissie voor de verzoekschriften en deze 
heeft thans geadviseerd den (nieuwen) gouverneur om inlichtingen te verzoeken. Men kan daar vrede mee hebben, indien dan maar ook de heeren van Putten c.s. aan het woord mogen komen. Want wat is er geschied?

In de reeds vermelde kamerzitting van 13 December 1928 zeide de Minister: „De waarnemende gouverneur van Curaçao" (de heer Mr. M. van Dijk, in de vacatureBrantjes) ,,zal voor eenige dagen naar St. Eustatius gaan”. Inderdaad was dit het plan. De heer van Dijk had in opdracht een onderzoek in te stellen naar het lot der arme bevolking, naar de hulp haar door genoemden heer Kruythoff verleend, naar het ongewenschte van de vereeniging onderwijzer-gezaghebber, en het sprak van zelf, dat hij daartoe rustig op het eiland zijn moest, dat hij iedereen moest te woord staan, onder vier oogen, omdat de menschen anders huiverig zouden zijn om te spreken, dat er dus geen pl.v.v. of waarn. gezaghebber bij zulke gesprekken tegenwoordig zouden zijn. Ja, dit sprak van zelf.

Welnu. Nadat Hr. Ms. Kortenaer eerst St. Maarten had aangedaan (dat niets geleden had) en de heer van Dijk onder veel feestbetoon daar drie dagen had doorgebracht, nadat men daarna op Saba (dat matig geleden had) twee dagen had vertoefd, kwam de Kortenaer den 20sten December 1928 voorm. 8.30 vóór St. Eustatius (dat zwaar geleden had). Men ontbood aanstonds den pl.v.v. gezaghebber aan boord, waar toen een langdurig onderhoud plaats vond tusschen $Z$. Exc., Lampe en hem. De heeren gingen 9.30 aan land, waarop enkele burgers gehoor vroegen. Zij vernamen toen, dat er geen audiëntie zou zijn, maar de heer Lampe bestelde hen tegen twee uur aan het raadhuis in fort Oranje, waar zij $Z$. Exc. zouden kunnen spreken. Zij kwamen met negen getuigen en wachtten tot 3.15. In arren moede gingen zij toen heen en vonden den heer Lampe staan in de deur van het huis zijner schoonzuster. Natuurlijk beklaagden zij zich en Lampe beloofde nog een onderhoud. Ten 3.30 kwamen toen $Z$. Exc., Lampe en Kruythoff bijéén, en voor deze drie heeren te zamen konden toen de anderen met hun grie- 
ven en klachten komen, maar toch wel zeer haastig en oppervlakkig, nademaal het gezelschap ongeveer 6 uur al weder op de Kortenaer was, die om 7 uur naar St. Maarten vertrok, daar Lampe aan wal zette en 9 uur de reis naar Curaçao vervolgde. Ziedaar het rustig bezoek van enkele dagen, de aanraking met de arme bevolking en het gehoor onder vier oogen!

De Minister zeide ook in diezelfde kamerzitting, dat de bijdragen voor leniging der ramp rijkelijk hadden gevloeid. Gelukkig. Doch hoe zijn ze gebruikt? De gouverneur van Curaçao stelde 16 September $f 5000$ ter beschikking van den heer Lampe. Ofschoon er op St. Maarten zelf geen schade was, hield hij $f 1000$ en gaf $f 2000$ aan St. Eustatius en Saba ieder. Op St. Eustatius heeft men dit geld m.n. gebruikt voor herstel van straten en wegen. Sedert kwamen voor de ramp een $f 21.000$ in. Men stortte dat geld op de Curaçaosche Bank, waar de heer Lampe er over kon beschikken, zoodat deze geen rekening en verantwoording aan de Rekenkamer behoefde te doen, zooals het geval zou geweest zijn, wanneer hij het via Administratie van Financiën ontvangen had. Nadat toen de heer Van Dijk van zijn bezoeksreis was teruggekeerd, ontbond zich, op zijn voorstel, het stormrampcomité, latende de richtige verdeeling der gelden aan de centrale en lokale gezaghebbers en hun comités. Er was toen (zonder dat ik op een enkelen gulden wil achterhaald worden) behalve die $f 21.000$ nog $f 1500$ uit het Antillenfonds te Willemstad en $f 3000$ hier te lande bijeengebracht te zamen rond $f$ 25.500. Doch op St. Eustatius heeft de heer Kruythoff geen commissie benoemd, om over de hem toebedeelde gelden te beschikken, zoodat hij daarin de vrije hand behield. Den 3den Januari dezer jaars bezocht de heer Lampe het eiland wederom, en het bleek toen, aldus luidt de klacht, dat behalve de dringendste herstellingswerken, men aan eigenlijke hulp der geslagen bevolking, aan het weder opbouwen der woningen, nog weinig of niets had gedaan.

Het is duidelijk, dat de heer Van Dijk dien 20sten December, na een verblijf van acht en een half uur op het 
eiland,noodwendig eenzijdig ingelicht naarCuraçao moest terugkeeren. Men mag dat niet vergeten, wanneer het heet dat de Statianen lui zijn, dat zij geen medewerking verleenden, alles van het gouvernement verwachtten, zelfs geen gevallen boomstam zonder betaling wilden wegruimen, dat zij een onsympathiek volk van krotbewoners zijn, en zoo verder. In deze kleine, arme maatschappij, van de wereld vergeten, met eene zoo gemengde bevolking, onder ongunstige oeconomische omstandigheden, zijn er natuurlijk ook slechte elementen, gelijk (als in vroeger eeuwen) persoonlijke veeten de verhoudingen troebel maken en de juistheid van oordeelen belemmeren. Indien er maar recht geschiedt. Indien thans maar - de vrienden van ons eiland begeeren niet anders - gouverneur Fruytier alle partijen hoort, een wezenlijk onderzoek instelt of voor 't minst doet instellen door onpartijdige en deskundige lieden. Indien daarvan dan maar een rapport wordt uitgebracht in klare taal, zonder omhaal, op den man af, opdat daaruit de voorstellen kunnen voortvloeien, die men aan het Plein zal moeten doen tot bestuurswijziging, tot landbouwopheffing en tot eene rechtvaardige behandeling der onbeschermde bevolking. St. Eustatius zij geen idyllisch Arcadië; waar vindt men dat op aarde? Doch zoo haar recht geschiedt, zoo het heldere licht opgaat over de verwaarloozing, door onkunde en door bitter vooroordeel haar aangedaan, dan zijn wij zeker dat men ook tot beter en gelukkiger gedachten komen zal omtrent land en volk in heden en toekomst.

De schrijver dezer bladzijden, die nimmer op het eiland was, is er zich wel van bewust, dat hij fouten heeft kunnen maken. Van de hoofdzaak mogen die de aandacht niet afleiden. Indien het hem maar gelukt zij, belangstelling te wekken of te verlevendigen voor dit kleine verzuimde stukje van het Nederlandsche Rijk! 
PRODUCTIE VAN SURINAME OVER DE LAATSTE ACHTTIEN JAREN

\begin{tabular}{|c|c|c|c|c|c|c|c|c|c|c|c|c|}
\hline Jaren & $\begin{array}{c}\text { Cacao in } \\
\text { balen van } \\
100 \text { Kilogr. }\end{array}$ & $\begin{array}{c}\text { Koffie in } \\
\text { balen van } \\
100 \text { Kilogr. }\end{array}$ & $\begin{array}{l}\text { Suiker } \\
\text { in tons }\end{array}$ & $\begin{array}{l}\text { Paddi } \\
\text { in tons }\end{array}$ & $\begin{array}{c}\text { Mais } \\
\text { in tons }\end{array}$ & $\begin{array}{l}\text { Cokos- } \\
\text { noten in } \\
\text { duizend- } \\
\text { tallen }\end{array}$ & $\begin{array}{c}\text { Aard- } \\
\text { vruchten } \\
\text { in } \\
\text { duizend- } \\
\text { tallen } \\
\text { kilogram. }\end{array}$ & $\begin{array}{c}\text { Bananen } \\
\text { in } \\
\text { duizend- } \\
\text { tallen } \\
\text { bossen }\end{array}$ & $\begin{array}{l}\text { Goud } \\
\text { in K.G. }\end{array}$ & $\begin{array}{l}\text { Balata } \\
\text { in tons }\end{array}$ & $\begin{array}{c}\text { Hout- } \\
\text { uitvoer- } \\
\text { waarde } \\
\text { in dui- } \\
\text { zendtall. } \\
\text { guldens }\end{array}$ & $\begin{array}{l}\text { Bauxiet } \\
\text { in tons }\end{array}$ \\
\hline 1911 & 13867 & 2688 & 14027 & 2195 & 1117 & 982 & 1016 & 460 & 955 & 1145 & 72 & - \\
\hline 1912 & 8640 & 1969 & 9634 & 2659 & 1291 & 968 & 1417 & 257 & 743 & 727 & 84 & - \\
\hline 1913 & 14782 & 3190 & 13244 & 2231 & 1076 & 822 & 1343 & 342 & 858 & 1186 & 128 & - \\
\hline 1914 & 14574 & 4810 & 15022 & 3136 & 878 & 876 & 1518 & & 919 & 1019 & 60 & - \\
\hline 1915 & 14652 & 6097 & 14747 & 5280 & 1168 & 1015 & 2025 & & 911 & 09 & 30 & - \\
\hline 1916 & 18709 & 7644 & 13032 & 7471 & 2254 & 1051 & 2307 & 520 & 798 & 769 & 31 & - \\
\hline 1917 & 19872 & 15460 & 14360 & 5338 & 1608 & 1449 & 4220 & 563 & 808 & 888 & 53 & - \\
\hline 1918 & 18877 & 18530 & 12086 & 8655 & 1874 & 2370 & 5571 & 734 & 586 & 681 & 31 & - \\
\hline 1919 & 13174 & 12824 & 7580 & 11388 & 1430 & 2468 & 4589 & 401 & 598 & 425 & 55 & - \\
\hline 1920 & 16023 & 17053 & 10077 & 9798 & 2078 & 2589 & 3991 & 385 & 470 & 444 & 244 & - \\
\hline 1921 & 15799 & 18124 & 11131 & 11797 & 1553 & 2216 & 3316 & 424 & 351 & 487 & 285 & - \\
\hline 1922 & 13606 & 25862 & 11906 & 12934 & 1713 & 2105 & 2085 & 48 & 37 & 546 & 142 & 1304 \\
\hline 1923 & 11606 & 28239 & 11785 & 10817 & 1538 & 2077 & 2160 & 489 & 369 & 629 & 146 & 12616 \\
\hline 1924 & 7951 & 16806 & 9068 & 16984 & 2206 & 2165 & 1885 & 480 & 323 & 555 & 80 & 60032 \\
\hline 1925 & 6956 & 25507 & 16612 & 13232 & 2582 & 2314 & 2031 & 520 & 309 & 735 & 130 & 86826 \\
\hline 1926 & 1402 & 17611 & 13965 & 16745 & 1718 & 1906 & 1855 & 378 & 259 & 563 & 232 & 46454 \\
\hline 1927 & 2107 & 30368 & 16736 & 14869 & 879 & 2233 & 1574 & 372 & 240 & 770 & 184 & 181584 \\
\hline 1928 & 2049 & 29238 & 18038 & 17476 & 916 & 2961 & 1658 & 348 & 171 & 511 & 318 & 213866 \\
\hline
\end{tabular}

Ontleend aan het Verslag uitgebracht door de Vereeniging voor Handel en Nijverheid in Suriname over 1928. 